\begin{tabular}{|l|l|}
\hline \multirow{2}{*}{ シンポジウム II } & 気管食道科領域における鏡視下手術（ビデオ） \\
\cline { 2 - 3 } & 気 道 系 \\
\hline
\end{tabular}

\title{
喉頭内視鏡手術一喉頭狭窄，喉頭麻痺を中心にして一
}

\author{
福田宏之*, 川井田 政弘**
}

\section{Endolaryngeal Surgery for Laryngeal Stenosis}

\author{
Hiroyuki Fukuda, M.D.* and Masahiro Kawaida, M.D.** \\ *Department of Otolaryngology, School of Medicine, Keio University, Tokyo and \\ **Tokyo Metropolitan Ohtsuka Hospital, Tokyo
}

Laryngeal or laryngotracheal stenosis still presents challenges for laryngologists. As the conditions of stenosis (size, location, partial or total) vary in each patient, we must make an effort to select a treatment method best suited to each patient. Depending on the type of stenosis, there are two major choices regarding surgery. One is the endoscopic technique, and the other is the open surgical procedure. In this paper, endoscopic procedures are described. Endoscopic procedures are mainly performed by laryngomicrosurgical techniques mainly with laser equipment.

A scar tissue or granulomatous tissue which narrows the laryngeal cavity is carefully excised or vaporized through a microlaryngoscope. This laser surgery is highly recommended because of minimized bleeding and ease of surgical manipulation. After dilation or enlargement of the laryngeal cavity is successfully obtained, the newly reconstructed cavity must be maintained, avoiding the recurrence of scar or granuloma formation. For this purpose, a silicone stent and a T-tube are widely used. However, we must design new stents and T-tubes for each patient. In this paper, our ideas on stents and T-tubes are reported.

Key words : 喉頭狭窄, ステント, Tチューブ

\section{I 、はじめに}

喉頭狭窄 (喉頭気管狭窄) の治療はいまだに われわれを悩ます疾患の一つである。治療内容 の歴史的変遷にもさまざまなものがあり，この 面で先達がいかに苦労したか村上"1 が総説とし て述べている。喉頭狭窄がなぜ治療困難なのか 理由を述べてみる。

*慶応大学医学部耳鼻咽喉科, **東京都立大塚病院 別刷請求： $=160$ 東京都新宿区信濃町35 慶応大学医学部耳鼻咽喉科 福田宏之

\section{——喉頭という蔵器の特殊性}

喉頭は気道であると同時に下気道の保護（喂 下作用）もしなくてはならないし，発声もしな くてはならない。そしてそれぞれの機能を発揮 しているときの喉頭内腔の形態的状態は，お互 いに著しく異なっている。たとえば，Tチュー ブを設置することが多いが, 先端の位置につい ても考元方が異なる。円谷 ${ }^{2,3}$ は, 肉芽の再発を 防ぐためチューブの先端は確実に声門上に出す べきとし，そのために起きる嗄声や誤飲はやむ を得ないとしている。 
一方田辺“ は, 声門下腔を十分に広げ,かつ声 帯に影響を与えないようにするためには，チュ ーブの先端は声門直下に置くべきであるとして いる。これで, ただ闇雲に喉頭内腔を広げれば よしとするほど単純なものではないと理解され る。

\section{狭窄に一定の規則がない}

気道の狭窄の程度, 範囲, 位置, 病態の経年 変化，それに成人か小児かなど症例により様々 であり, 症例の数だけ病態があると言ってよい ほどである。したがって，治療法も症例の数だ け存在すると考えてもよく，治療にあたっては 症例ごとに治療方法を選択すべきである。

\section{一治療完了までに長期間を要する}

内腔保持のためにステントやTチューブを設 置するが, ある程度の期間が必要で, 完了した と思っても成功に至らず，他の方法に移行せざ るを得ないこともおきる。傾向としては，なる たけ手術侵襲の少ないものから選択するような 場合に問題がある。また治療期間が長いことは, それだけ不測の事態が生じる可能性が強いこと もあげなくてはならない。気道の管理に精力的 に当たらなくてはならず，これは医療当事者ば かりでなく, 患者周囲の者にまで緊張を強いる ことになる。

\section{II．治 療}

まず狭窄を起こしている原因を除去する。狭 窄の原因の大部分は喉頭麻痺を除けば，癒着， 瘢痕, 肉芽様組織であるから，これを摘除する。 内腔が確保されたらその内腔の維持のための工 夫をする。内腔の維持とは, 創面が上皮化され てから形態が固定化されるまでをいう。それら の原因除去のために喉頭内視鏡下で行う場合 と,喉頭気管を開いて直視下に行う場合とある。 除去にレーザーを用いるのはいまでは普通にな っている。喉頭気管を開放した場合, 即座に T チューブを挿入して閉鎖することもあるが, $\mathrm{QSS}^{5}$ を内腔の形状に応じて形成し, モールド とし, 留置すれば清掃や消毒がたやすくよいと する報告もある。

2 次手術として閉鎖させなくてはならない が，単純に縫合するだけで成功する症例は少な い。特に小児の場合, 何らかの工夫が必要で,
補強材として肋軟骨6.7)を用いたりする場合も ある。最近では，アパタイトセラミックを気管 軟骨状に形成して用いる報告もある8》。村上 ${ }^{11}$ は, 喉頭全摘時に採取して，アルコール保存で きる気管軟骨 homograft のほうが弾力性に優 れていて納まりもよいと述べている。

\section{III．喉頭内視鏡手術}

これは喉頭内視鏡下に癒着, 痽痕などを除去 し，ステントもしくはTチューブを挿入してお く方法である。狭窄の部位が声門下腔より気管 側まで広がりのあるものは適応外である。最も
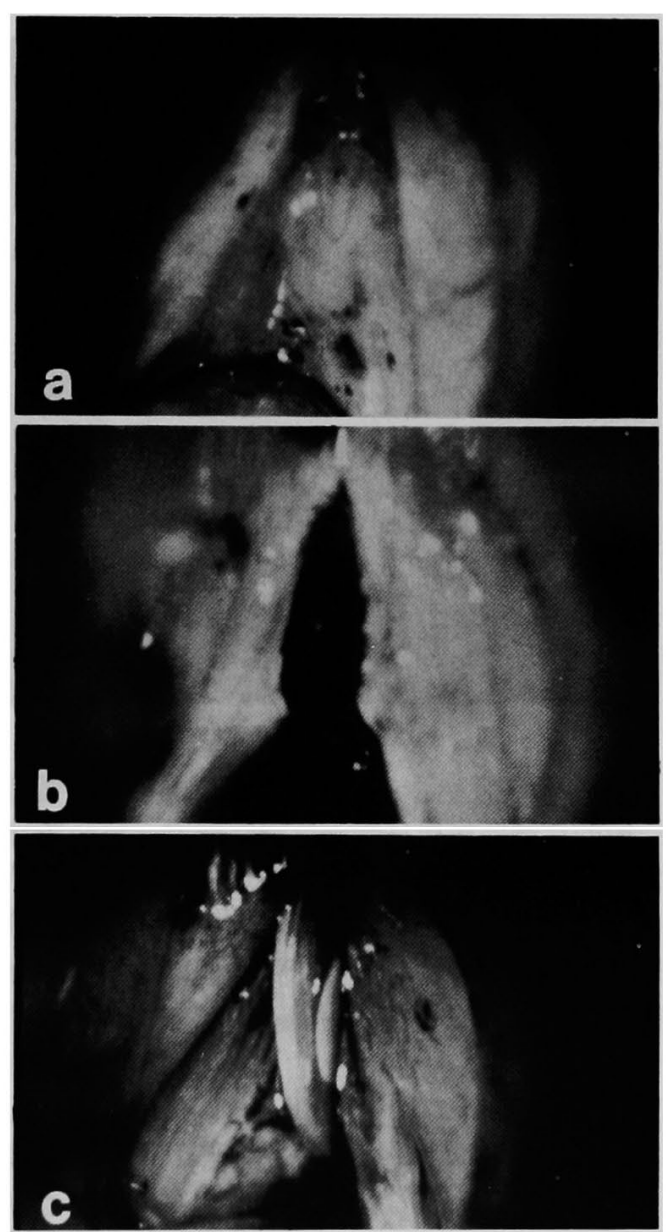

図 1 従来のステントを用いた喉頭横隔膜症の喉頭 内視鏡下手術

$\mathrm{a}$ ：術前, $\mathrm{b}$ ：横隔膜を切離したところ, $\mathrm{c}$ ：ステント を挿入したところ。 


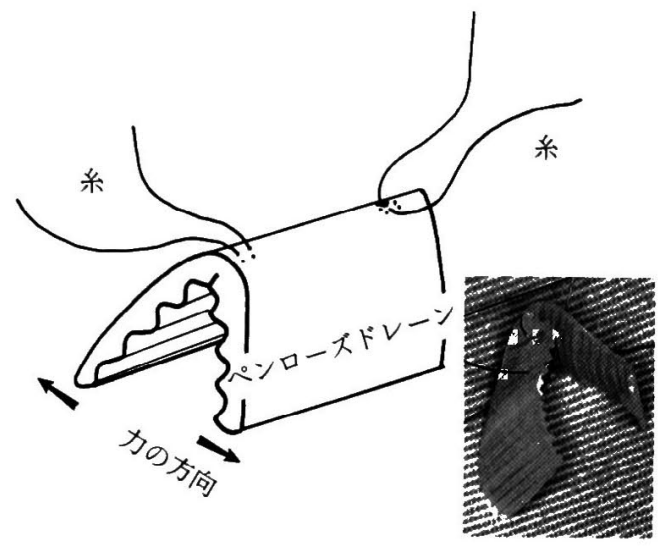

図 2 新しくエ夫されたステント

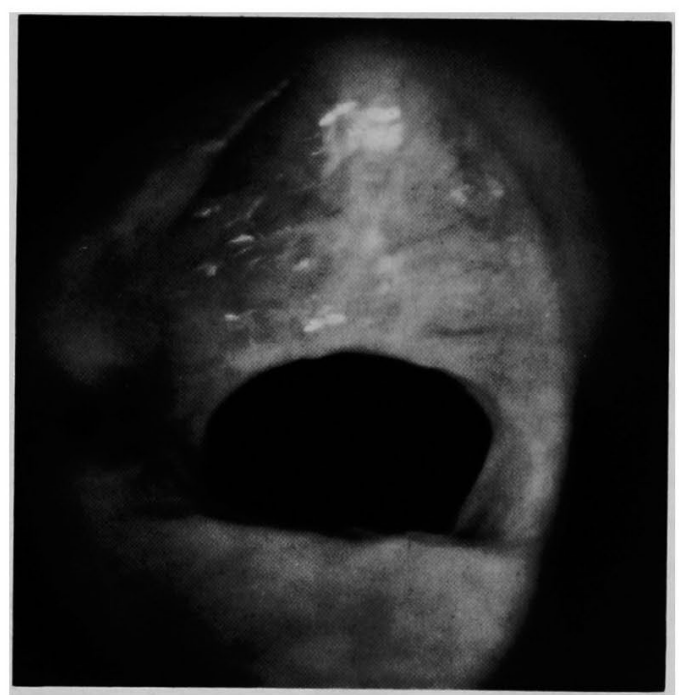

図 3 高度喉頭横隔膜症

一般的な適応疾患は喉頭横隔膜症で, レーザー で癒着部位を切離したのち普通の市販のシリコ ンステントを挿入しておき, 両側の声帯の再癒 着を防ぐ(図 1 )。この方法は簡便で手術侵襲も 少ないという優れた点がある。

\section{IV. ステントのエ夫}

しかし最近ステントが入手困難となり，また サイズの種類も少ないという欠点がある。それ で吉田ら ${ }^{9)}$ はペンローズドレーンを細工してス テントとして用いている。われわれも，この方 法はいつでも入手しやすい材料であり，症例に 応じて加工できるので都合がよいと考える。わ

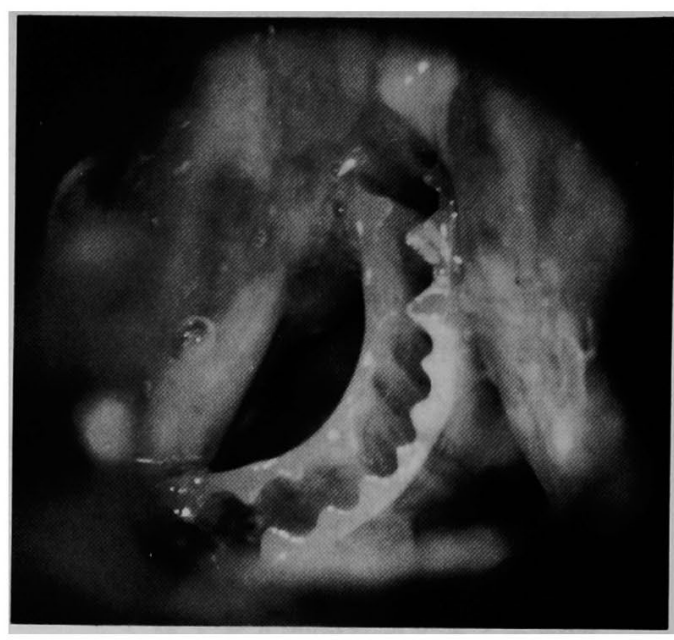

図4新しくエ夫されたステントを挿入したところ

れわれの作製するペンローズドレーン応用のス テントを図 2 に示す。

ステントは 2 翼からなり, 逆に折り曲げてあ るので広がろうとする力が外方に働き, ステン トとしては力学的にも都合も良いものになって いる。これを応用したのが図 3 の症例である。

患者は72歳男性で, 長期間の気管内扦管を余 儀なくされ, 高度の喉頭狭窄症（横隔膜）とな つたものである。この症例に対して自作のステ ントを挿入したところが図 4 である。この症例 は, 現在のところ経過良好である。この方法の 優れている点は，大きさが適宜調節でき， 2 翼 であり, 再癒着を防ぐばかりでなく, 疫痕拘縮 をもある程度防げることにある。

\section{V . Tチュープのエ夫}

喉頭から気管へかけての広範囲のものや, 冹 痕拘縮の強いもので内腔を長期間維持しなくて はならないような症例ではステントだけでは有 効でない。例えば声門全周の疲痕で, 喉頭内腔 を新たに再建しなくてはならないような症例で ある。この場合は Tチューブを用いるようにな るが, 問題はある。Tチューブの先端は声門を 越えて上方に固定されなくてはならないが, 誤 飲が予想されるし, 気管側のチューブの太さで は気道保持に不安が残る。これらで苦労し, 結 果としてTチューブを工夫することによって, 7 年ぶりに気管カニューレを外すことに成功し 


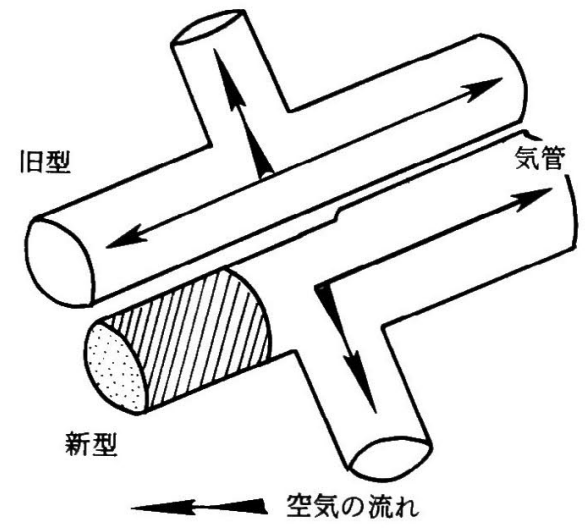

図 5 新型のTチューブ

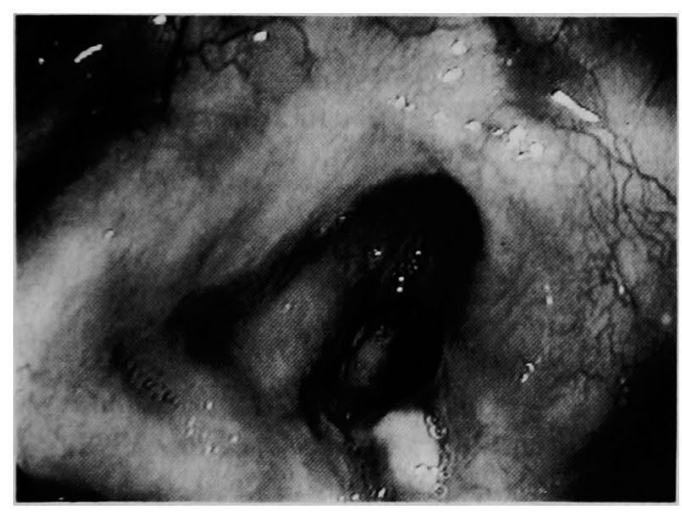

図 6 Tチュープ挿入前

た症例を提示し，そのTチュープを紹介する。

\section{VI. 症例}

昭和55年（1980年）生，女性。

喉頭乳頭腫のためわれわれ受診(1989年 2 月) までに 7 回のレーザー手術を受けた。その後も 再発が多発し, 頻回のレーザー手術をうけるこ とになる。あるときは喉頭を開いての手術など

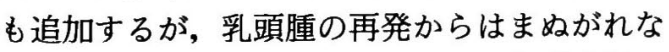
かった。当然喉頭はつぶれており, 気道確保の ため89年 3 月に気管切開をうけ, カニューレと ともに生活するようになる。1989年11月の手術 後は, 乳頭腫は気管に少量認めるも増大傾向な く, 1989年12月より漢方治療を開始した。その 結果, 1991年 7 月より乳頭腫が消失。漢方療法 が1994年 2 月まで続けられた。そこでもはや乳

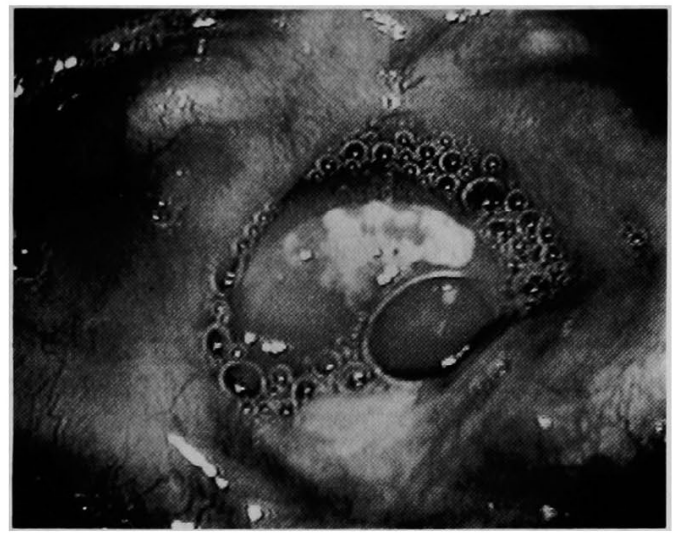

図 7 Tチューブ挿入直後

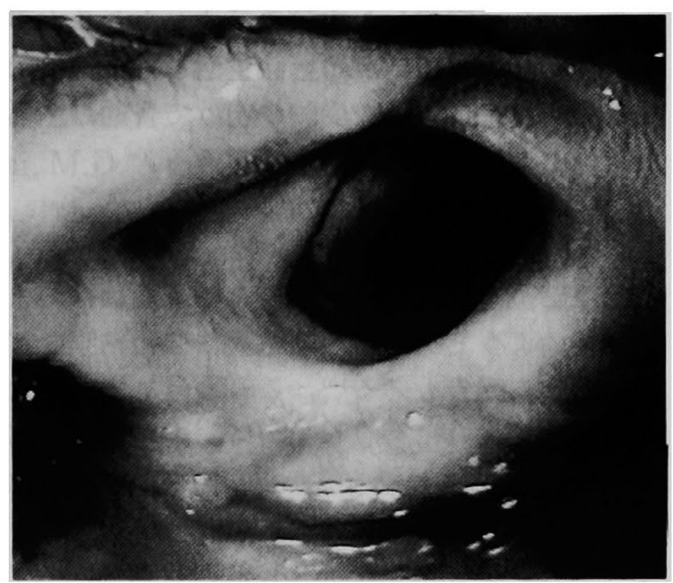

図 8 術後 1 力月の喉頭内腔

頭腫から解放されたと判断し, 喉頭内腔の再建 を行った。

始めに市販のシリコンプレートを用いたが, 声門上への距離が足りなく, 肉芽で埋もれる結 果となった。そこで, これも市販で手にはいる Tチューブを用いたが，誤飲がはなはだしく上 部に栓をした。これで誤飲は防ぐことができた が，今度はチューブ内に瘡蓋が付着し呼吸困難 となる。そのためこのTチューブも抜かざるを えなくなった。そこでTチューブに工夫が必要

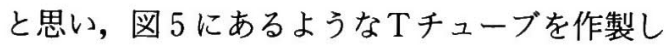
た。

図 5 の上方は従来のもので, 太さはあらゆる 方向で均一である。われわれの工夫したものは 
図 5 の下方に示すが, 太さは均一でなく, 気道 となる部分は他に比べて若干太くしてある。さ らに声門に突き出るほうはソリッドとして内腔 をつぶしてある。これを用いて1995年 6 月, 再 度喉頭内腔を確保してからこの $\mathrm{T}$ チューブを挿 入した。誤飲もなく気道も十分保持されている ことを確認して退院。1995年11月 9 日全身麻酔 下で喉頭を観察したのち，Tチューブを抜去し てテフロンカニューレを挿入。夕刻より誤飲な く経口摄取可能となった。また翌日よりカニュ ーレに栓をしても呼吸困難なく11月13日カニュ ーレ抜去，21日気管孔を閉鎖，28日退院となっ た。

図 6 に ころ, 図 8 に完成した内腔を示す。もちろん声 の質は良好ではないが，社会生活を行う上では 十分である。現在高校受験に向けて普通の生活 が送れるようになったところである。

\section{VII. おわりに}

狭窄部位を除去したあと，この創面は裸のま まが多いようであるが, 煩粘膜や口唇粘膜など を移植する報告もある10)。この場合フィブリン 糊の開発が大いに寄与していて, 再瘾着防止に 用いられる11) ほどであるから，将来の応用には 期待するものがある。場合によってはステント などの必要がなくなるかもしれない。

\section{文献}

1）村上 泰：喉頭気管狭窄.日気食会報, $41 ： 326-$ 335,1990 .

2 ) 円谷英一：小児声門下狭窄症の問題点と治療 法. 耳鼻臨床, 74：904-907, 1981.

3 ) 円谷英一, 石橋 康, 松井道夫 - 他：小児声門 下狭窄症の手術的治療. 日気食会報, $31: 393-$ 400,1980 .

4) 田辺正博, 土師知行, 楠本健夫・他: 幼小児の喉 頭, 気管狭窄の治療. 日気食会報, $33: 281-286$, 1982.

5 ) Okada, K., Murakami, Y., Ikari, T., et al. : Surgical treatment of laryngotracheal stenosis by a trough technique. Auris Nasus Larynx, 12 : Suppl 2, 78-80, 1985.

6 ) Cotton, R. : Management of subglottic stenosis in infancy and childhood. Ann. Otol., 87:649-657, 1978.

7 ）川城信子, 古賀慶次郎，村上説子：小児声門下 㹟窄に対する外科的治療一自家肋軟骨移植によ

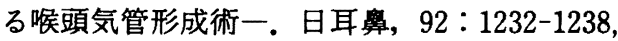
1989.

8 ）平野 実, 吉田哲二, 坂口伸治・他：喉頭気管 の再建における水酸化アパタイトの利用. 日気 食会報, 38：1-10, 1987.

9）吉田幸夫, 斎藤 等, 斎藤武久 - 他 : 搌頭, 気 管狭窄の 4 治験例. 耳鼻臨床, 補63：147-153, 1993.

10）平野 滋, 森 一功, 児嶋久剛 - 他：声門下狭 窄の一治験例一フィブリン糊を用いた粘膜移植 法一. 日気食会報, $42: 368-371,1991$.

11）川崎順久, 福田宏之,ドミンゴス辻・他：フィ フリン接着剤の顕微鏡下レーザー手術への応 用. 日気食会報, $41: 236-240,1990$. 